\title{
Section 46 - why it
}

\section{was included}

The PNG Government is trying to 'shoot the messenger'. The danger is that if the Government shoots the messenger today, who will bring them the message they are eagerly looking forward to receiving tomorrow?

\section{By JOHN MOMIS}

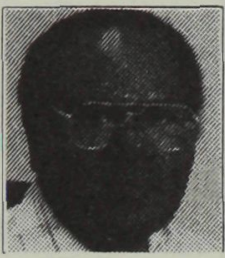

WHY WAS Section 46 - freedom of expression - included in the Constitution? The Constitution of Papua New Guinea, like the constitutions of all truly democratic nations anywhere in the world today, has, as its cornerstone, the belief in the supremacy of the human being, over every other creature of institution in the entire universe. We as Christians believe that God made man in his own image and likeness and placed him in charge of everything he created. Man is God's masterpiece, the pinnacle of his creation, and distinguished from every other creature by virtue of his intellect and his free will. We further believe that man is not only a creature, but in fact thanks to the pascal mystery of Jesus Christ our saviour, also a co-creator, capable of intelligently and freely transforming his society and thus determine his own destiny.

Freedom, the ability to choose, is one of man's inalienable rights. Freedom is what defines him and therefore separates him from the animals, vegetables and minerals. Man is endowed with a number of other basic rights. You can go as far back as you like in recorded human history, and you will find along his footprints indelible imprints of his struggles in protecting, defending or asserting his dignity, his rights, and his freedoms from those who tried to take those off him through oppression, domination, and suppression. The United Nations formally recognised those innate human rights and freedoms and these are contained in its Universal Declaration of Human Rights, adopted in 1948.

I don't want to get too dogmatic or philosophical about this, except to stress that acceptance or acknowledgement of the principle or belief in the supremacy 


\section{Human rights}

\section{The Universal Declaration of Human Rights adopted by the United} Nations in 1948.

1. The right to live

2. The right not to be tortured or made a slave

3. The right not be imprisoned without a fair trial in court.

4. The right not to be subjected to arbitrary interference with privacy, family, home or communications.

5. The right to freedom of thought, conscience and religion.

6. The right to speak freely, to join an association, and to hold public meetings.

7. The right to take part in the government of his country, directly or through freely chosen representatives.

8. The right not to be arbitrarily deprived of one's property.

9. The right to work, to free choice or employment and to just and favourable conditions of employment

10. The right to a standard of living adequate for the health and well being of each person and his family.

11. The right to an education.

\section{Human Rights Ordinance 1971}

1. The right to life

2. The right to personal liberty

3. Freedom from slavery and forced labour

4. Freedom from inhuman treatment

5. The right to protection of property

6 . The right to protection from arbitrary search and entry on premises.

7. Protection of law to ensure no imprisonment except on a proper charge and after a fair trial.

8. Freedom of though, conscience and religion

9. Freedom of speech and the right to publish.

10. Freedom of peaceful assembly and association

11. Freedom of choice of employment

of the human being or mankind over every other creature or institution on earth is a pre-condition to understanding both the letter and the spirit of our Constitution. And with that acknowledgement comes the realisation that the Constitution is after all only a document that spells out a nation's formal institutional 
arrangements which reaffirm and protect those innate rights and freedoms of each citizen. The Constitution does not give its citizens any rights or freedoms at all; rather it is a formal recognition, a formal acknowledgement, a formal guarantee, and a formal protection of the citizens innate rights and freedoms.

But to get back to our original question: Why was Section 46 - freedom of expression - included in the Constitution?

The human rights and freedoms contained in the Universal Declaration of Human Rights unfortunately were not enforceable in a court on law. And we in Papua New Guinea, all too familiar with authoritarian governments after having been ruled by them for over 90 years, felt that even though the English common law and the Australian statute law which we inherited under colonial rule theoretically provided substantial protection of human rights and freedoms, discriminatory local legislation and lack of access to independent legal advice prevented our people from effectively asserting their rights.

However, Papua New Guinea did have a specific law which provided protection of human rights and freedom similar to those adopted by the UN the Human Rights Ordinance 1971. It was introduced into the House of Assembly by a private member of the House, the Rev Percy Chatterton, MHA, soon after the enactment of the controversial Public Order Ordinance 1970.

The Public Order Ordinance allowed the Government (Administration) to restrict processions and public meetings, and included a number of new offences relating to demonstrations and other forms of civil disobedience. It gave rise to much strong criticism to the effect that it unjustifiably limited basic democratic freedoms, and that it was an attempt to suppress the efforts of Papua New Guineans seeking to recover land rights on the on the Gazelle Peninsula. The Human Rights Ordinance was seen as a reassertion of the basic democratic freedoms in the light of a move by the Administration to impose significant restrictions upon the fundamental rights and freedoms of Papua New Guineans. Under the Human Rights Ordinance, all of those rights and freedoms were enforceable by the full Supreme Court.

Because of overwhelming demand that the protection of rights and freedoms in an independent Papua New Guinea be given high priority, and serious concerns that simple laws such as an ordinance or an Act of Parliament could be easily changed depending on the whims of the government of the day, the Constitutional Planning Committee recommended that all eleven rights and freedoms set out in the human rights ordinance be included in the Constitution.

\section{Section 46: Freedom of expression}

On this particular freedom, the CPC noted that one of the great principles on which democracy rests in the right to differ on any topic of discussion, be it 
social, economic, political, cultural or religious. People view any issue in different ways, and we in the CPC believed firmly that they should have the right to express their own views, within very broad limits, on any particular matter, and that in principle every citizen should be free to criticise the policies of the government of the day. The media has a particular responsibility in this regard, as unless those who wish to express independent opinions are reported in the media, their effectiveness is likely to be much reduced, and the opportunity for meaningful debate on important public issues may be lost. The formation and expression of public opinion is vital to the kind of participatory democracy we believed our people wanted.

In framing our recommendations, we closely followed the equivalent provision in the ordinance which made particular reference to freedom of the press. Of course, 'freedom of the press' does not mean freedom without responsibility. In an emerging nation such as Papua New Guinea, we believed the media had a very important responsibility to report news accurately, and to give equal opportunities and facilities for the expression by the citizens of opposing or differing views.

\section{Section 51: Freedom of information}

Closely related to Section 46 of the Constitution is Section 51 - the right to freedom of information wherein every citizen has the right of reasonable access to official documents, subject only to the need for such secrecy as is reasonably justifiable in a democratic society in respect of matters relation to national security, defence, and so forth. We believed that for our citizens to be able to participate effectively in the public affairs of this country, it was essential that they have access to official information. Without that information, a person cannot make a meaningful contribution to discussion of the issues involved in government policies and programs. The degree to which citizens are able to fully participate in debate on the public affairs of the country will be a good measure of the extent to which our system of government is truly democratic.

Governments in many countries fail to communicate effectively to their people the actions they are taking or contemplating, and the problems which face them. Sometimes this is due to sheer inefficiency on the part of the Government Information Office, but sometimes it is a case of the Government wanting to keep from the voters the truth about matters which might cause loss of support for the Government if they were widely known. In this context, the $\mathrm{CPC}$ believed the media would become an active instrument in constantly promoting people's awareness and consciousness, and not a mere functionary indifferent to the Government's policies for the people's problems and aspirations. The media is really not at liberty to stand by and watch the Government 
beat its people into submission through domination or oppression. Section 46, and all those other rights and freedoms, come with responsibilities and obligations as well. In our final report, we spelt those obligations out very clearly as constitutional, political, social and economic obligations. Let me quote what we said about political obligations:

The governing of our country should be a collective and concerted effort. It is not a job for the ministers and members of parliament only. It is not simply a job for those in the public service. If we are to have good government in this country - government which is responsive to the needs and wishes of the people - all of our people should participate in accordance with the rights they have under the Constitution and any law made in accordance with it. Not only political parties are involved trade unions and other associations should make their contributions to political life also. So too should the media, churches and those in public employment and in private enterprise. But above all, our people as individuals, as members of village and urban communities, and as citizens of our country should make their contribution, however small or large, if we are to have a government of the people.

As you can see Section 46 in our Constitution - freedom of expression - does not exclusively mean freedom of the press. No. Section 46 was primarily intended for the citizens of this country, to be exercised together with their constitutional, economic, social and in particular their political obligations which I have just outlined.

This is a very important qualification of Section 46, especially when it comes to the issue of media accountability To whom is the media accountable? And the answer is obvious: The media is accountable to the citizens of this country from whom it derives its freedom.

Legalists can argue on this. But speaking as deputy chairman of the CPC. I can tell you now that as we were considering this particular section, foremost in our minds was the roles and obligations of our people as citizens who through the exercise of their rights to freedom of expression would contribute meaningfully towards the promotion and enhancement of a higher quality of politics and good government for this country. A responsible media would promote and facilitate the exercise of that freedom. But lack or absence of the media did not in itself mean that the people's rights under Section 46 had been forfeited, nor that they had to forgo that right. Not at all. It is a freedom that they are entitled to under the Constitution, with or without the presence of the media fraternity.

Implicit in Section 46 of course is the understanding that there would be a free and independent press through which every citizen would be able to exercise 


\section{JOHN MOMIS}

that freedom. In fact Section 46 (1) states that 'freedom of expression...' includes '...freedom of the press and other mass communications media....'

So to answer the question Why was Section 46 included in the Constitution?, I would have to repeat what I have said many times before: the vision of the founding fathers of our Constitution was that our nation would evolve through a participatory democracy into a just and egalitarian society in which everyone is equal, with equal rights and opportunities to realise his or her own potential as a human being, while at the same time respecting the rights of others. Section 46 provides the legal avenue through which our people, as citizens, can fulfil their political obligations to their country.

Having said that now I want to make a few general remarks about the present situation. I am curious to know how media accountability as a topic came to be included on the CRC's agenda. But looking at the countries it visited recently - Indonesia, Singapore, Malaysia, China and Thailand - it is apparent that media censorship rather than media accountability was its real motive because that is what all those countries have in common. CRC chairman Ben Micah announced upon his arrival back from that Asian tour that press freedom in Papua New Guinea would not be touched. Why? Because the delegation realised that imposing media censorship here would not be so easy because our people have achieved a high degree of sophistication in their perception of their right to freedom of expression, and would not give that freedom up without a fight.

I see a far more serious scenario though. As you all know, Parliament has abolished the previous provincial government system in favour of the recent reforms. No matter how you look at it, the new reform puts all power and authority in the central Government. Sure all the responsibilities have been transferred to the local level governments. But the real authority remains in Waigani.

Some people are more straightforward: They call it structural patronage, in which the Government reduces the people to a total dependency status and thereby making them very vulnerable to manipulation through handouts.

The scenario gets worse as we contemplate the long-term implications of recent Government reforms and legislation such as provincial government reforms, Internal Security Act, the Ok Tedi Supplementary Bill, proposed amendments to the Forestry Act, the proposed Media Bill, uncontrolled privatisation, uncontrolled exploitation of our natural resources, increasing dependence on foreign imports and increasing exports to pay back foreign debts.

The above moves point to a Government which has set out to systematically disempower Papua New Guinean citizens and reduce them to mere recipients of goods and services by denying them their basic constitutional rights, 
freedoms and obligations. The current trends in our country attach the sovereignty of our people and of our land. And it is no wonder that people are now experiencing political powerlessness in the face of economic rationalism and institutionalised patronage; an ideology used to justify oppression of people for economic gain by particular grouns. This is the trail left by a Government that has no trust in its people, and is suspicious of them. This is neo-colonialism. And the problems at Bougainville, Ok Tedi, Porgera, Lihir, and Kutubu and so on are all rejections by the people of this new form of colonialism. Mark my words, the worst is still to come if the people perceive that their rights, freedoms, obligations and human dignity are threatened.

I have been concerned, for quite some time, about the current level of politics, which I think is very low indeed; slow in fact that while the quality of life for our people is now at its lowest, we politicians continue to bask in the sunshine of our own inflated sense of self-importance to the nation. You can tell us all the problems and suffering our people have had to endure, and we politicians always have a way of explaining them away or glossing over them.

I felt that the level of our politics was so pathetic that our concepts of truth, equality, integrity, and so on were being challenged. There is a conspicuous lack of ethical dimension in our political and economic conduct. I even released a media statement to all concerned Papua New Guineans titled: 'Papua New Guinea Threatened by a Crisis of Truth'. I sent it to two media outlets. Only one printed it. My 50 per cent success rate made me wonder if the media and I shared the same definition of truth. My being a politician is coincidental.

I wrote that as a concerned citizen trying to communicate with other concerned citizens about the way our nation was being governed. We are all worried about the gags imposed on the media from without. But in my experience, I am more worried about the gags that are imposed from within.

I judge the media not so much by what it disseminates, but by what it chooses not to disseminate. At the end of the day, the only real criteria for assessing media accountability is whether it has given equal opportunities and facilities for the expression by the citizens of opposing or differing views, which in essence is what Section 46 of the Constitution is all about. That is the media role the CPC anticipated. How successful has the media been in fulfilling that role? I leave that to your own conscience.

John Momis is regional member for Bougainville in the PNG National Parliament and former Communications Minister. He was also deputy chairman of the Constitutional Planning Committee before independence. This paper was presented at the 'Freedom at the Crossroads' media seminar organised by the PNG Media Council in Port Moresby, 29 February-1 March 1996. 